\title{
Effects of paternal alcoholism on the psycho- behavioral outcomes of children: systematic review and meta-analysis
}

PKB Mahesh ( $\sim$ buddhikamaheshpk@gmail.com )

RDHS Office, Colombo https://orcid.org/0000-0002-9037-5142

Janni Leung

University of Queensland

S.J. Senanayake

Ministry of Health, Sri Lanka

Vindya Kumarapeli

Ministry of Health

Ruwan Ferdinando

National Institute of Health Sciences

Deirdre McLaughlin

University of Melbourne

Research article

Keywords:

Posted Date: June 25th, 2019

DOl: https://doi.org/10.21203/rs.2.10655/v1

License: (1) This work is licensed under a Creative Commons Attribution 4.0 International License.

Read Full License 


\section{Abstract}

Introduction: Documented literature includes mixed interpretations of the impact of paternal alcoholism on psycho-behavioral well-being in children. A systematic review and a meta-analysis would facilitate the accurate establishment of this association. Aim: To evaluate the effects of paternal alcoholism on the psycho-behavioral well-being of children by a systematic review with a meta-analysis and a narrative review component Methods: This PROPERO registered review (CRD42018114754) was conducted by reviewing searching literature in MEDLINE, EMBASE and PsycINFO databases. Twenty nine articles out of 16398 were selected for data extraction after three selection rounds. Thirteen were included in the metaanalyses for four numerical outcomes and two categorical outcomes. Meta-analysis outcomes included; internalizing behavior, externalizing behavior, depression and anxiety. Heterogeneity, risk of biases and the quality of evidence were assessed. Sensitivity analysis was done by re-analyzing with random-model assumption following the fixed model assumption. Furthermore re-analysis with standardized mean difference was done following the analysis with mean difference. Rev Man (version 5.3) software and "GRADEproGDT" online applications were used. Summary of Findings Tables were prepared. A narrative review was done with studies and sub-groups not included in the meta-analysis, under five identified themes: depression and mood disorders; self-perceived mental health problems and personality; aggression; ADHD and other problems. Results: With meta-analysis, all four numerical outcomes for demonstrated significant mean differences (MD) with higher values in the group with paternal alcoholism. "Low" level was assigned as the GRADE certainty. For the anxiety when it is regarded as a categorical outcome, the resulting relative effect was significant ( $\mathrm{OR}=2.18,95 \% \mathrm{Cl}=2.03$ to 2.33 ) with "Moderate" certainty. In sensitivity analysis, associations of similar directions were observed. Narrative review reflected other negative psycho-behavioral consequences of children associated with paternal alcoholism, falling under the five identified themes. Conclusions: Robust findings were observed for the positive associations of paternal alcoholism with the selected psycho-behavioral pathologies of children in the meta-analysis. The narrative review further demonstrated negative implications of paternal alcoholism on five identified thematic areas.

\section{Introduction}

It is estimated that around $43 \%$ of the people 15 years and above, were "current drinkers" in 2016 with a considerable variation worldwide. Nearly a quarter of alcohol consumption in the world and more than half in South East Asia was categorized as "unrecorded"(1). Alcohol-use is within the top ten risk factors (seventh in 2016) of death and DALYs(2). Out of the substance use disorders, alcohol use has been the most common (3). Strategies to prevent alcoholism have been emphasized globally owing to the recent epidemic of chronic Non Communicable Diseases (NCDs) to which excess alcohol consumption contributes. The achievement of Sustainable Development Goals is regarded as only possible if interventions are implemented to address the alcohol burden $(1,3)$.

In addition to its direct health related effects, alcoholism has legal, economic and social implications. Having an alcoholic in the household is assumed to influence the children in diverse ways. In a study 
done among Korean students, it was revealed that childhood exposure to an alcoholic or substance abuser has a 2.37 (1.41-3.98) times likelihood of being diagnosed with "definite depression" and 2.11 (1.18-3.76) times chance of potentially developing alcoholism (4). In a Chilean study it was revealed that the consumption of alcohol in the household leads to an increase in the child witnessing physical violence and verbal violence as well as economic problems resulting in the inability of families to provide the optimum care for the child(5). A Norwegian study reported alcohol abuse by parents as an independent risk factor for the school related attention and conduct problems,(6). Higher prevalence of corporal punishment was reported among the heavy alcoholics towards three year old children in United States(7). Additionally, parental drinking patterns influence the intake of alcohol by the children(8-12).

Though many of the studies have explored "parental alcoholism", in the majority of the families, problem-drinking was more likely to be associated with the father than with the mother(13). The specific influence of paternal drinking on children has been explored in literature. Social competence of the children is affected by the paternal alcoholism(14). Paternal alcoholism is further associated with negative parental behaviors and attachments $(15,16)$. Among youth with depression, those with positive family history of paternal alcoholism were even found to be with changes in electroencephalograms (17). In addition, marital satisfaction has been found to be decreased with paternal alcoholism(18). Even in lower-middle income settings like Sri Lanka, the available limited literature implies the negative consequences of paternal alcoholism(19). This leads to a vicious cycle leading to a decreased bond between the father and the children, yielding more negative psycho-behavioral effects on children. Bad parental-relationships were associated with suicidal ideation in a study done among French adults(20).

Yet some studies have demonstrated that there is no difference between the emotional and behavioral problems of the children in relation to the alcohol intake status of their parents(13). Similarly, some literature has demonstrated significant effects of mothers' intake but not that of the father(21). Furthermore some researches have documented that in general, children of alcoholic parents could "manage quite well"(21). However in some of these studies which have depicted negative associations, several limitations have been highlighted, including small sample sizes.. Hence, a systematically reviewed literature with meta-analysis could help in correctly establishing the effects of paternal influence on psycho-behavioral well-being of children.

Behavioral disorders of children are conventionally classified as internal (inward directing) and external (demonstrated to the external environment). Externalizing behaviors of children include; "lack of compliance with social norms, lower emotional control and associated interpersonal aggressiveness (22). In contrast, internalizing disorders are directed inwards and reflect the child's psychological and emotional state $(23,24)$. These encompass a diverse group of conditions which include; "depression, withdrawal, and anxiety, as well as feelings of inferiority, self-consciousness, shyness, hypersensitivity, and somatic complaints" $(23,24)$. There is an overlap between externalizing behaviors and internalizing disorders and hence, the term psycho-behavioral would be more appropriate in representing a comprehensive scope of the dynamics and interactions related to these. 
This systematic review includes five meta-analyses done on the effects of paternal alcoholism on four defined psycho-behavioral outcomes of children. Additionally this includes a narrative review component covering a broader range of outcomes, for the selected studies or their sub-groups those were not included in the meta-analysis.

\section{Methods}

\section{Protocol and registration}

The review was done according to the PRISMA (i.e. Preferred Reporting Items for Systematic Reviews and Meta-analyses) guidelines(25). Registration of the review was done in the PROSPERO-International prospective register of systematic reviews registration (CRD42018114754).

\section{Eligibility criteria}

The PICOS sequence of the research question(26) was whether "paternal alcoholism incurs effects compared to its absence, on the psychological and behavioral outcomes of children". The selection criteria of the studies included; studies having a quantifiable effect measure related to psychological or behavioral well-being of children and including a paternal specific-analysis. Psychological or behavioral well-being outcomes of interest included; depression, anxiety, internalizing behavioral, externalizing behavior, self-perceived mental well-being, personality, aggression, Attention Deficit Hyperactive Disorder (ADHD) and non-compliance. Outcomes on suicidal ideation, parental attachment, alcohol-use of children, and education attainment of children were outside the scope of this review and excluded.

\section{Search strategy}

The literature search was done in MEDLINE, EMBASE and PsycINFO databases. Search strategies were finalized with the inputs of a research librarian (Supplementary material- Annex I-III). The period covered in the search approximately included 20 years (i.e. from $1^{\text {st }}$ of January 1998 to $24^{\text {th }}$ of December 2018). Unpublished articles were searched by contacting the expert colleagues in the related fields. Additionally, the reference lists of selected articles were searched for potential articles. After compiling the manuscript, additional searches were done for any new articles.

When the data required for meta-analysis were not available in the manuscript, attempts were made to contact the respective corresponding authors through emails. When findings of selected studies were not completely available for the meta-analysis, those studies or their sub-groups were included in the narrative synthesis.

\section{Selection of studies}

Three rounds of selections were done. In the first round, duplicated articles and those not consistent with the general objective of the review were excluded. Abstracts were reviewed in the first round. Full articles were reviewed from the second round onwards. In the second round, articles were reviewed for the 
outcome and the study design. Merely qualitative manuscripts and studies with non-matching outcomes for the scope of the review were excluded. In the third round of selection, the characteristics of the exposed/ non-exposed groups were reviewed. Manuscripts with discrepancies of the defined exposure and which did not include a paternal-specific analysis were excluded. The flow diagram of the selection process is illustrated in Figure 1.

\section{Data-extraction}

Data extraction was done using a pre-designed template. The extracted variables are summarized in Figure 2. When several follow up measurements were available in a single selected study for metaanalysis, the last wave of data collection was selected for the extraction.

\section{Estimation of bias}

A risk of bias table (Table 3 ) for the selected studies for the meta-analysis was prepared having referred the necessary recommendations for observational studies(55). Subsequently Funnel plots were used for assessing publication bias (56).

\section{Meta-analysis and narrative synthesis}

The assessment for statistical heterogeneity of the selected studies was done with chi-square and Isquare tests for all the meta-analyses $(56,57)$. The cut-offs of the l-square test for heterogeneity and for the $p$ value of chi-square test were considered as $50 \%$ and 0.1 respectively $(56,58)$. Following the heterogeneity assessments, Review Manager (version 5.3) application was used for the metaanalysis(59) with pooling done by Mantel- Haenszel method. Initially fixed-model assumptions were followed. For assessing the robustness of the findings, sensitivity analysis was done by re-performing the meta-analysis with random-method assumption $(60,61)$. Mean Difference (MD) with its confidence interval $(\mathrm{Cl})$ was used as the effect measure for continuous measurements. Following this, re-analysis was done with Standardized Mean Difference (SMD) as another step in sensitivity analysis. Odds Ratio (OR) was used for the categorical variables. When studies have provided gender-specific effect measures without a combined measure, they were separately included as sub-groups in the meta-analysis. When the studies that met inclusion criteria did not have data for inclusion in the meta-analysis, they were used for narrative synthesis $(62,63)$. Summary of Findings table was synthesized for the findings of the metaanalysis (64). GRADE criteria were used in assessing the quality. "GRADEproGDT" online application was used in this regard $(55,65,66)$.

\section{Results}

At the end of the three rounds of selection, 13 studies were selected for meta-analysis. Table 1 summarizes their characteristics.

The articles selected only for the narrative review have been summarized in Table 2 . 
The risk of bias estimates of the selected articles for the meta-analyses have been mentioned in Table 3 . To impart an impartial judgment, for all studies the "failure of confounding control" was mentioned as "unclear risk". As all the studies used validated instruments, for "flawed measurements" the bias was estimated to be of "low risk".

The Summary of Finding tables for the numerical outcomes as well as for the categorical outcomes are shown respectively in Tables 4 and 5. As shown in Table 4, for the numerical outcomes of depression, anxiety, internalizing behavior and externalizing behaviors, significant mean differences were noted. The measurements had been higher for the exposed (i.e. father alcoholic) group.

A significantly higher relative effect $(\mathrm{OR}=2.18,95 \% \mathrm{Cl}=2.03-2.33)$ was noted for the exposed group (i.e. with paternal alcoholism) for the occurrence of childhood anxiety among children when analyzed as a categorical outcome.

The sensitivity analysis was done by re-doing the meta-analysis using SMD and with the random model assumptions. The observed effect measures remained statistically significant demonstrating the robustness of the findings (Table 6).

Even though meta-analysis of three studies(32,33,37) (Singh-2017, Jacob-1999 and Jacob-2000) yielded a pooled Odds Ratio of 1.68 ( $95 \mathrm{Cl}=1.28$ to 2.20$)$ for depression as a categorical outcome, statistical heterogeneity was noted $\left(I^{2}=74 \%\right)$. Hence those findings were described in the narrative review section below.

The Figures $3 A$ to $7 A$ shows the Forrest plots for the mentioned meta-analyses. Immediately below, Figures $3 \mathrm{~B}$ to $7 \mathrm{~B}$ demonstrate the Funnel plots drawn for selected studies.

The narrative review based on the articles or outcomes of articles which were not included in the metaanalyses is described below

\section{Depression and mood disorders}

When fathers are active-problem drinkers, children were found to have 1.56 times greater likelihood of having depressive symptoms ( $95 \% \mathrm{Cl}=1.24-1.96)$. Even when stratified for gender, significantly higher likelihoods were observed for males $(\mathrm{OR}=1.75,95 \% \mathrm{Cl}=1.14-2.68)$ and females $(\mathrm{OR}=1.49,95 \% \mathrm{Cl}=1.13$ 1.96)(47). In the study by Jacob \& Windle (2000), the RDC-depression percentages were $35.9 \%$ and $33.3 \%$ respectively for the exposed and control groups(33). Following structural equation modeling, done with data collected among undergraduate students, it was revealed that paternal alcoholism had a "total effect on depressive symptoms" (beta coefficient $=0.118,95 \% \mathrm{Cl}=0.006$ to $0.230, \mathrm{p}=0.039)(54)$. In a study done in California, a slight increase of depression was noted in the group with paternal alcoholism amidst gender differences(32). A North Indian study revealed a significant association between the 
alcohol use of the father and depression in the school children(37). A non-significant independent association with "drinking father" and depression was found by Kelley et al (2010)(46).

Similarly, mood disorders were higher among the exposed group (18.6\% to $7.0 \%) .(48)$ The problem drinking of the father was associated with an increased life time risk of mood disorders among children(48). Malone, Lacona \& McGue (2002) showed that paternal alcoholism is associated with depression among 17 year old offspring but not at 14 years(41).

\section{Self-perceived mental health problems and personality}

In a longitudinal study done in United States, the SF-12 mental health index values were found to be worse for the children of alcoholic fathers even at age 40, compared to those of non-alcoholic fathers (39). In the study by Jacob and Windle (2000), for the five domains (i.e. extraversion, neuroticism, agreeableness, conscientiousness and openness to experience) assessed by NEO-Personality Inventory, the children of alcoholic fathers reported less favorable outcomes compared to children with nonalcoholic fathers(33).

\section{Aggression}

Edwards et al (2006b) conducted a study to explore aggressive behavior of children who experienced paternal alcoholism. It was found that, by 48 months, $22 \%$ of children were in the clinical range for aggression in the father-alcoholic group compared to $5.4 \%$ in the non-alcohol group(49).

As concluded by Grekin and others (2005), paternal alcoholism is a predictor of both violent and nonviolent delinquency at age 15(52). The study by Finan et al (2015) showed that paternal alcoholism was a direct predictor for aggressive behavior for boys. For both girls and boys indirect associations of paternal alcoholism and aggressive behavior of children were demonstrated(51). Malone, Lacono \& Mcgue (2002), showed the positive association of paternal alcoholism with disruptive behaviors(41). In a study done in Croatia, it was revealed that the auto-aggressiveness of school students was associated with paternal alcoholism in the univariate analysis but not in the multivariate analysis(44).

\section{Attention Deficit Hyperactive Disorder (ADHD)}

In a twin study done by Knopik et al (2005), paternal alcohol dependence was significantly associated with $\operatorname{ADHD}(\mathrm{OR}=2.11,95 \% \mathrm{Cl}=1.39-3.22)(40)$. With further studies, this association was suspected to be influenced by indirect pathways(45). The association between paternal alcoholism and ADHD at 17 years was shown in a study done in Minnesota, United States(41). In another study, the standardized incidence ratio of $A D H D$ among children who experienced paternal alcoholism was 2.15 (95\% $\mathrm{Cl}=2.11$ and 2.20$)$ (43).

\section{Other problems}


Having a father with problem-drinking has been found to a significant predictor for getting 1 or more psychiatric disorders in 12-months $(O R=1.47, p<0.05)$ or over the life time $(O R=2.00, p<0.05)(48)$. In the study by Foley et al (2001), it was revealed that paternal alcoholism alone is not significantly associated with psychiatric symptoms of children. However when it is comorbid with paternal or maternal depression, the risk of children developing increased levels of a number of diverse conditions, including separation anxiety, depression, conduct symptoms and oppositional defiant behavior is increased(67).

In a study by Keller et al (2008), it was revealed that the paternal alcoholism is indirectly associated with internalizing and externalizing problems. The data collections were done while the children were in kindergarten and in the following two years(53). In the study by Adkison et al (2013), it was revealed that the association between paternal alcoholism and poor self-regulatory strategies of children may reemerge in early adolescence(38). In the study of Eiden Leonard and Morrisey (2001), sons of fathers with

alcohol-problems demonstrated higher rates of non-compliance on four measures of compliance than the children without alcoholic fathers(50).

In a 15 year follow up study, Raitasalo et al (2018) concluded that, for both girls and boys, paternal alcohol use is associated with a higher likelihood of "mental and behavioral disorders" among children. (42). Similarly a higher proportion (10.6\%) was "ever diagnosed" with mental-health problems compared to the no-problem drinking parent group (6.2\%). Similarly $7.1 \%$ of the exposed group, compared to a $3.7 \%$ of the no-problem drinking category had a mental health problem diagnosed in the previous 12 months (39)

\section{Discussion}

This is the first systematic review with meta-analyses that evaluate the effects of paternal alcoholism covering a comprehensive scope of psycho-behavioral outcomes of children. Most of the pre-existing literature on related aspects, do confine to a narrow set of outcomes. Since psychological well-being and behavioral dynamics are inter-related, this review provides a better understanding of the association between paternal alcoholism versus the selected outcomes. The results reveal that the influence of paternal alcoholism extends throughout the life cycle of their offspring. Negative consequences generated by the said exposure include associations with internalizing behaviors, externalizing behaviors, anxiety, depression, personality disorders, impairment of self-perceived mental health, aggression, ADHD and non-compliance in children.

All the five meta-analyses done showed that there are significant negative outcomes in relation to depression, anxiety, internalizing behavior and externalizing behaviors of children. The robustness of these findings was verified with the unchanged findings following the sensitivity analysis. Both internalizing and externalizing behaviors of children lead to negative consequences (22-24). Some of these could be hidden and hard to detect. As an example, depression is associated with a high economic burden and is often undiagnosed(68). Anxiety is also found in high prevalence in the community, often undiagnosed and commonly associated with comorbidities(69). These disorders also influence the social 
competence of those affected(24). In addition to the outcomes in the meta-analyses, the outcomes described in the narrative review highlight the negative influence of paternal alcoholism on the psychobehavioral outcomes of children.

The study populations in the review include under-five category, adolescents, university students and adults as well. Negative implications of paternal alcoholism were observed for all these categories. This further strengthens the robustness of the findings and implies that the impact of paternal alcoholism extends throughout the life cycle of the children. Even in the studies that did not document a direct significant association between psychiatric issues and paternal alcoholism, positive associations have been noted when the exposed group was with associated comorbidities such as paternal depression (67). It is well-noted that the paternal alcoholism is associated with conditions such as reduced quality of marital relationships and behaviors which may make the father prone to depressive symptoms $(14,18)$. This further complements the finding that paternal alcoholism does influence the psycho-behavioral wellbeing of the offspring through indirect pathways.

There are two main implications of this review as far as policy planners are concerned. Firstly the psycho-behavioral aspects of the children of alcoholic fathers need to be given adequate emphasis. Policy planners must come up with strategies in accurately detecting positive paternal alcoholics as acceptable to the specific settings. The second is that the findings can be used in targeting behavior change of the alcoholics at appropriate settings. Sessions for newly married couples and ante-natal health education sessions for both parents are two such fora which can be used for this.

Most of the studies retained after the selection process have been conducted in Western settings. This implies that childhood mental health outcomes are less commonly evaluated in other settings, including lower and lower-middle income settings in which the chronic NCD burden is relatively high. The second inference may be that, even if such evaluations have been done, fewer publications are reported from such settings, suggesting that a greater focus on research and subsequent publication of results should be encouraged.

There is available literature on the mediating effects of other variables which influence these associations. Ohannessian (2015) reported that both maternal and paternal problem-drinking must be taken into context when interpreting the paternal effect on adolescent adjustment(70). It was shown that when paternal alcohol consumption was high, anxiety and depression symptomatology in children was lower when the problem drinking of the mother was low. It was also noted that there are significant interactions of the gender of the child on mental health conditions(35). These aspects must be explored more with further research.

There were several limitations of the study. No extensive effort was done in searching non-English articles. However the search strategy was not limited to English articles. The English abstracts of nonEnglish articles which were in the databases were reviewed. However, none of the non-English articles were selected (owing to the eligibility criteria) to be included in the review, beyond the second round. The quality of evidence for numerical-outcome related meta-analyses was graded as "low". This is because 
by default, the observational studies are started with a lower baseline of evidence level due to their nonrandomized nature. Thirdly a subgroup analysis on the level of alcohol intake was not done. However this was taken into consideration in the interpretation of findings. Furthermore, to address this issue, in the evaluation of the level of quality, upgrading was not done for "dose response".

Another limitation was the different time periods at which the outcome measurements had been done even when the tools were meant to measure the similar constructs. Yet the authors are confident in stating this has not resulted in biased estimates due to several reasons. Firstly all selected studies had used validated instruments in assessing the exposures and the outcomes. Secondly, in selection of the studies, clinical, methodological as well as statistical heterogeneity were taken into account $(71,72)$. Thirdly the similar significant associations were observed when the meta-analysis was re-done getting SMD as the effect measure for numerical outcomes.

\section{Conclusions}

Positive associations of paternal alcoholism with the selected psycho-behavioral pathologies of children were detected in the meta-analysis. These findings are found to be robust with sensitivity analysis. The narrative review further demonstrated negative implications of paternal alcoholism on five identified thematic areas. Further research must be promoted especially focusing on the mediators of these associations.

\section{Abbreviations}

ADHD- Attention Deficit Hyperactive Disorder

CAPA-C- Child and Adolescent Psychiatric Assessment-Children's Version

CBCL- Child Behavior Checklist

DSM- Diagnostic and Statistical Manual of Mental Disorders EMBASE- Excerpta Medica Database

GRADE- Grading quality of evidence and strength of recommendations

GRADEproGDT: GRADE guideline development tool

ICD- International Classification of Diseases

MD- Mean Difference

MEDLINE- Medical Literature Analysis and Retrieval System Online

NEO-Personality Inventory- Neuroticism-Extraversion-Openness Inventory

OR- Odds Ratio

Page 10/29 
PICOS sequence: Population-Intervention-Comparison-Outcome-Study sequence

PRISMA guidelines: Preferred Reporting Items for Systematic Reviews and Meta-analyses guidelines

PROSPERO- International prospective register of systematic reviews

PsycINFO- Database of abstracts of literature in the field of psychology produced by American Psychological Association

SADS-L- Schedule for Affective Disorders ad Schizophrenia-the lifetime version SMD- Standardized Mean Difference

SF-12-Short Form 12

RDC- Research Diagnostic Criteria

UM-CIDI- University of Michigan Composite Diagnostic Index

\section{Declarations}

Ethics approval and consent: Not applicable.

Consent for publication: Not applicable.

\section{References}

1. World Health Organization. WHO | Global status report on alcohol and health 2018 [Internet]. Geneva; 2018. Available from: http://apps.who.int/iris/bitstream/handle/10665/274603/9789241565639eng.pdf?ua $=1$

2. Griswold MG, Fullman N, Hawley C, Arian N, Zimsen SRM, Tymeson HD, et al. Alcohol use and burden for 195 countries and territories, 1990-2016: a systematic analysis for the Global Burden of Disease Study 2016. Lancet [Internet]. 2018 Sep;392(10152):1015-35. Available from: https://linkinghub.elsevier.com/retrieve/pii/S0140673618313102

3. Degenhardt L, Charlson F, Ferrari A, Santomauro D, Erskine H, Mantilla-Herrara A, et al. The global burden of disease attributable to alcohol and drug use in 195 countries and territories, 1990-2016: a systematic analysis for the Global Burden of Disease Study 2016. The Lancet Psychiatry [Internet]. 2018 Nov; Available from: https://linkinghub.elsevier.com/retrieve/pii/S2215036618303377

4. Kim YH. Associations of adverse childhood experiences with depression and alcohol abuse among Korean college students. Child Abuse Negl. 2017 May;67:338-48.

5. Florenzano R, Echeverria A, Sieverson C, Barr M, Fernandez MA. [Alcohol's impact on children and families. A population survey]. Rev Chil Pediatr. 2016;87(3):162-8. 
6. Torvik FA, Rognmo K, Ask H, Roysamb E, Tambs K. Parental alcohol use and adolescent school adjustment in the general population: results from the HUNT study. BMC Public Health. 2011 Sep;11:706.

7. Lee SJ, Perron BE, Taylor CA, Guterman NB. Paternal psychosocial characteristics and corporal punishment of their 3-year-old children. J Interpers Violence. 2011 Jan;26(1):71-87.

8. Vermeulen-Smit E, Koning IM, Verdurmen JEE, Van der Vorst H, Engels RCME, Vollebergh WAM. The influence of paternal and maternal drinking patterns within two-partner families on the initiation and development of adolescent drinking. Addict Behav. 2012 Nov;37(11):1248-56.

9. Sorensen HJ, Manzardo AM, Knop J, Penick EC, Madarasz W, Nickel EJ, et al. The contribution of parental alcohol use disorders and other psychiatric illness to the risk of alcohol use disorders in the offspring. Alcohol Clin Exp Res. 2011 Jul;35(7):1315-20.

10. Chen C-Y, Storr CL, Liu C-Y, Chen K-H, Chen WJ, Lin K-M. Differential relationships of family drinking with alcohol expectancy among urban school children. BMC Public Health. 2011 Feb;11:87.

11. Trim RS, Schuckit MA, Smith TL. Predicting drinking onset with discrete-time survival analysis in offspring from the San Diego prospective study. Drug Alcohol Depend. 2010 Mar;107(2-3):215-20.

12. Peiponen S, Laukkanen E, Korhonen V, Hintikka U, Lehtonen J. The association of parental alcohol abuse and depression with severe emotional and behavioural problems in adolescents: a clinical study. Int J Soc Psychiatry. 2006 Sep;52(5):395-407.

13. Pajarn $P$, Theeranate $C$. Impact of parental alcohol consumption on emotional and behavioral problems in children age 3-4 years. J Med Assoc Thai. 2012 May;95 Suppl 5:S6-11.

14. Eiden RD, Colder C, Edwards EP, Leonard KE. A longitudinal study of social competence among children of alcoholic and nonalcoholic parents: role of parental psychopathology, parental warmth, and self-regulation. Psychol Addict Behav. 2009 Mar;23(1):36-46.

15. Eiden RD, Leonard KE, Hoyle RH, Chavez F. A transactional model of parent-infant interactions in alcoholic families. Psychol Addict Behav. 2004 Dec;18(4):350-61.

16. Edwards EP, Eiden RD, Leonard KE. IMPACT OF FATHERS' ALCOHOLISM AND ASSOCIATED RISK FACTORS ON PARENT-INFANT ATTACHMENT STABILITY FROM 12 TO 18 MONTHS. Infant Ment Health J. 2004 Nov;25(6):556-79.

17. Dahl RE, Williamson DE, Bertocci MA, Stolz M V, Ryan ND, Ehlers CL. Spectral analyses of sleep EEG in depressed offspring of fathers with or without a positive history of alcohol abuse or dependence: a pilot study. Alcohol. 2003 Jul;30(3):193-200.

18. Kachadourian LK, Eiden RD, Leonard KE. Paternal alcoholism, negative parenting, and the mediating role of marital satisfaction. Addict Behav. 2009 Nov;34(11):918-27.

19. Sriskandarajah V, Neuner F, Catani C. Predictors of violence against children in Tamil families in northern Sri Lanka. Soc Sci Med. 2015 Dec;146:257-65.

20. Legleye S, Beck F, Peretti-Watel P, Chau N, Firdion JM. Suicidal ideation among young French adults: association with occupation, family, sexual activity, personal background and drug use. J Affect Disord. 2010 Jun;123(1-3):108-15. 
21. Rognmo K, Torvik FA, Ask H, Roysamb E, Tambs K. Paternal and maternal alcohol abuse and offspring mental distress in the general population: the Nord-Trondelag health study. BMC Public Health. 2012 Jun;12:448.

22. Brook JS, Zhang C, Balka EB, Brook DW. Pathways to Children's Externalizing Behavior: A ThreeGeneration Study. J Genet Psychol [Internet]. 2012 Apr;173(2):175-97. Available from: http://www.tandfonline.com/doi/abs/10.1080/00221325.2011.594821

23. LIU J, CHEN X, LEWIS G. Childhood internalizing behaviour: analysis and implications. J Psychiatr Ment Health Nurs [Internet]. 2011 Dec;18(10):884-94. Available from: http://doi.wiley.com/10.1111/j.1365-2850.2011.01743.x

24. Bornstein MH, Hahn C-S, Haynes OM. Social competence, externalizing, and internalizing behavioral adjustment from early childhood through early adolescence: Developmental cascades. Dev Psychopathol [Internet]. 2010 Nov 1;22(04):717-35. Available from: http://www.journals.cambridge.org/abstract_S0954579410000416

25. Johansen M, Thomsen SF. Guidelines for Reporting Medical Research: A Critical Appraisal. Int Sch Res Not [Internet]. 2016;2016:1-7. Available from: http://www.hindawi.com/journals/isrn/2016/1346026/

26. Methley AM, Campbell S, Chew-Graham C, McNally R, Cheraghi-Sohi S. PICO, PICOS and SPIDER: a comparison study of specificity and sensitivity in three search tools for qualitative systematic reviews. BMC Health Serv Res [Internet]. 2014 Dec 21;14(1):579. Available from: http://bmchealthservres.biomedcentral.com/articles/10.1186/s12913-014-0579-0

27. Edwards EP, Leonard KE, Eiden RDAS. TEMPERAMENT AND BEHAVIORAL PROBLEMS AMONG INFANTS IN ALCOHOLIC FAMILIES. Infant Ment Health J. 2001 May;22(3):374-92.

28. Edwards EP, Eiden R Das, Leonard KE. Behaviour problems in 18- to 36-month old children of alcoholic fathers: secure mother-infant attachment as a protective factor. Dev Psychopathol. 2006;18(2):395-407.

29. Choi DH, Kim JS, Jung JG, Ryou Y II, Kim YS, Uh WC. The role of paternal drinking problems in the psychological characteristics of high school students. Korean J Fam Med. 2013 Nov;34(6):377-84.

30. Eiden RD, Molnar DS, Colder C, Edwards EP, Leonard KE. A conceptual model predicting internalizing problems in middle childhood among children of alcoholic and nonalcoholic fathers: the role of marital aggression. J Stud Alcohol Drugs. 2009 Sep;70(5):741-50.

31. Haugland BSM. Paternal Alcohol Abuse: Relationship between Child Adjustment, Parental Characteristics, and Family Functioning. Child Psychiatry Hum Dev. 2003;

32. Jacob T, Windle M, Seilhamer RA, Bost J. Adult children of alcoholics: Drinking, psychiatric, and psychosocial status. Psychol Addict Behav. 1999;

33. Jacob T, Windle M. Young adult children of alcoholic, depressed and nondistressed parents. J Stud Alcohol. 2000 Nov;61(6):836-44.

34. Loukas A, Fitzgerald HE, Zucker RA, von Eye A. Parental alcoholism and co-occurring antisocial behavior: prospective relationships to externalizing behavior problems in their young sons. J Abnorm 
Child Psychol. 2001 Apr;29(2):91-106.

35. Morgan PT, Desai RA, Potenza MN. Gender-related influences of parental alcoholism on the prevalence of psychiatric illnesses: analysis of the National Epidemiologic Survey on Alcohol and Related Conditions. Alcohol Clin Exp Res. 2010 Oct;34(10):1759-67.

36. Puttler LI, Zucker RA, Fitzgerald HE, Bingham CR. Behavioral outcomes among children of alcoholics during the early and middle childhood years: Familial subtype variations. Alcohol Clin Exp Res. 1998;

37. Singh MM, Gupta M, Grover S. Prevalence \& factors associated with depression among schoolgoing adolescents in Chandigarh, north India. Indian J Med Res [Internet]. 2017 Aug;146(2):205-15. Available from: http://www.ncbi.nlm.nih.gov/pubmed/29265021

38. Adkison SE, Grohman K, Colder CR, Leonard K, Orrange-Torchia T, Peterson E, et al. Impact of Fathers' Alcohol Problems on the Development of Effortful Control in Early Adolescence. J Stud Alcohol Drugs. 2013;

39. Balsa Al, Homer JF, French MT. The health effects of parental problem drinking on adult children. J Ment Health Policy Econ. 2009 Jun;12(2):55-66.

40. Knopik VS, Sparrow EP, Madden PAF, Bucholz KK, Hudziak JJ, Reich W, et al. Contributions of parental alcoholism, prenatal substance exposure, and genetic transmission to child ADHD risk: a female twin study. Psychol Med. 2005 May;35(5):625-35.

41. Malone SM, lacono WG, McGue M. Drinks of the Father: Father's Maximum Number of Drinks Consumed Predicts Externalizing Disorders, Substance Use, and Substance Use Disorders in Preadolescent and Adolescent Offspring. Alcohol Clin Exp Res. 2006;

42. Raitasalo K, Holmila M, Jääskeläinen $M$, Santalahti P. The effect of the severity of parental alcohol abuse on mental and behavioural disorders in children. Eur Child Adolesc Psychiatry [Internet]. 2018 Nov 14; Available from: http://link.springer.com/10.1007/s00787-018-1253-6

43. Sundquist J, Sundquist K, Ji J. Autism and attention-deficit/hyperactivity disorder among individuals with a family history of alcohol use disorders. Elife [Internet]. 2014 Aug 19;3. Available from: https://elifesciences.org/articles/02917

44. Tripkovic M, Franciskovic T, Grgic N, Ercegovic N, Graovac M, Zecevic I. Family Factors Associated with Auto-aggressiveness in Adolescents in Croatia. Coll Antropol. 2013;

45. Knopik VS, Jacob T, Haber JR, Swenson LP, Howell DN. Paternal Alcoholism and Offspring ADHD Problems: A Children of Twins Design. Twin Res Hum Genet [Internet]. 2009 Feb 21;12(01):53-62. Available from: http://www.journals.cambridge.org/abstract_S1832427400009592

46. Kelley ML, Braitman A, Henson JM, Schroeder V, Ladage J, Gumienny L. Relationships among depressive mood symptoms and parent and peer relations in collegiate children of alcoholics. Am J Orthopsychiatry. 2010 Apr;80(2):204-12.

47. Chen Y-Y, Weitzman ER. Depressive symptoms, DSM-IV alcohol abuse and their comorbidity among children of problem drinkers in a national survey: effects of parent and child gender and parent recovery status. J Stud Alcohol. 2005 Jan;66(1):66-73. 
48. Cuijpers P, Langendoen Y, Bijl R V. Psychiatric disorders in adult children of problem drinkers: prevalence, first onset and comparison with other risk factors. Addiction. 1999 Oct;94(10):1489-98.

49. Edwards EP, Eiden RD, Colder C, Leonard KE. The development of aggression in 18 to 48 month old children of alcoholic parents. J Abnorm Child Psychol. 2006 Jun;34(3):409-23.

50. Das Eiden R, Leonard KE, Morrisey S. Paternal Alcoholism and Toddler Noncompliance. Alcohol Clin Exp Res. 2001;

51. Finan LJ, Schulz J, Gordon MS, Ohannessian CM. Parental problem drinking and adolescent externalizing behaviors: The mediating role of family functioning. J Adolesc [Internet]. 2015 Aug;43:100-10. Available from: https://linkinghub.elsevier.com/retrieve/pii/S0140197115000950

52. Grekin ER, Brennan PA, Hammen C. Parental alcohol use disorders and child delinquency: the mediating effects of executive functioning and chronic family stress. J Stud Alcohol. 2015;

53. Keller PS, Cummings EM, Davies PT, Mitchell PM. Longitudinal relations between parental drinking problems, family functioning, and child adjustment. Dev Psychopathol. 2008;20(1):195-212.

54. Kelley ML, Pearson MR, Trinh S, Klostermann K, Krakowski K. Maternal and paternal alcoholism and depressive mood in college students: parental relationships as mediators of ACOA-depressive mood link. Addict Behav. 2011 Jul;36(7):700-6.

55. Guyatt GH, Oxman AD, Vist G, Kunz R, Brozek J, Alonso-Coello P, et al. GRADE guidelines: 4. Rating the quality of evidence-study limitations (risk of bias). J Clin Epidemiol [Internet]. 2011 Apr;64(4):407-15. Available from: http://linkinghub.elsevier.com/retrieve/pii/S0895435610004130

56. Bown MJ, Sutton AJ. Quality Control in Systematic Reviews and Meta-analyses. Eur J Vasc Endovasc Surg [Internet]. 2010 Nov;40(5):669-77. Available from:

http://linkinghub.elsevier.com/retrieve/pii/S1078588410004387

57. Melsen WG, Bootsma MCJ, Rovers MM, Bonten MJM. The effects of clinical and statistical heterogeneity on the predictive values of results from meta-analyses. Clin Microbiol Infect [Internet]. 2014 Feb;20(2):123-9. Available from:

http://linkinghub.elsevier.com/retrieve/pii/S1198743X14600458

58. Conway A, Clarke MJ, Treweek S, Schünemann H, Santesso N, Morgan RL, et al. Summary of findings tables for communicating key findings of systematic reviews. In: Conway A, editor. Cochrane Database of Systematic Reviews [Internet]. Chichester, UK: John Wiley \& Sons, Ltd; 2017. Available from: http://doi.wiley.com/10.1002/14651858.MR000044

59. Israel H, Richter RR. A Guide to Understanding Meta-analysis. J Orthop Sport Phys Ther [Internet]. 2011 Jul;41(7):496-504. Available from: http://www.jospt.org/doi/10.2519/jospt.2011.3333

60. Schroll JB, Moustgaard R, Gøtzsche PC. Dealing with substantial heterogeneity in Cochrane reviews. Cross-sectional study. BMC Med Res Methodol [Internet]. 2011 Dec 24;11(1):22. Available from: http://bmcmedresmethodol.biomedcentral.com/articles/10.1186/1471-2288-11-22

61. Brugha TS, Matthews R, Morgan Z, Hill T, Alonso J, Jones DR. Methodology and reporting of systematic reviews and meta-analyses of observational studies in psychiatric epidemiology: 
systematic review. Br J Psychiatry [Internet]. 2012 Jun 1;200(6):446-53. Available from: http://bjp.rcpsych.org/cgi/doi/10.1192/bjp.bp.111.098103

62. Campbell M, Thomson H, Katikireddi SV, Sowden A. Reporting of narrative synthesis in systematic reviews of public health interventions: a methodological assessment. Lancet [Internet]. 2016 Nov;388:S34. Available from: http://linkinghub.elsevier.com/retrieve/pii/S014067361632270X

63. Snilstveit B, Oliver S, Vojtkova M. Narrative approaches to systematic review and synthesis of evidence for international development policy and practice. J Dev Eff [Internet]. 2012 Sep;4(3):40929. Available from: http://www.tandfonline.com/doi/abs/10.1080/19439342.2012.710641

64. Langendam MW, Akl EA, Dahm P, Glasziou P, Guyatt G, Schünemann HJ. Assessing and presenting summaries of evidence in Cochrane Reviews. Syst Rev [Internet]. 2013 Dec 23;2(1):81. Available from: http://systematicreviewsjournal.biomedcentral.com/articles/10.1186/2046-4053-2-81

65. Balshem H, Helfand M, Schünemann HJ, Oxman AD, Kunz R, Brozek J, et al. GRADE guidelines: 3. Rating the quality of evidence. J Clin Epidemiol [Internet]. 2011 Apr;64(4):401-6. Available from: http://linkinghub.elsevier.com/retrieve/pii/S089543561000332X

66. GRADE working group. Grading quality of evidence and strength of recommendations. BMJ [Internet]. 2004 Jun 19;328(7454):1490-0. Available from: http://www.bmj.com/cgi/doi/10.1136/bmj.328.7454.1490

67. Foley DL, Pickles A, Simonoff E, Maes HH, Silberg JL, Hewitt JK, et al. Parental concordance and comorbidity for psychiatric disorder and associate risks for current psychiatric symptoms and disorders in a community sample of juvenile twins. J Child Psychol Psychiatry. 2001 Mar;42(3):38194.

68. Williams SZ, Chung GS, Muennig PA. Undiagnosed depression: A community diagnosis. SSM - Popul Heal [Internet]. 2017 Dec;3:633-8. Available from: https://linkinghub.elsevier.com/retrieve/pii/S2352827317301064

69. Kasper S. Anxiety disorders: under-diagnosed and insufficiently treated. Int J Psychiatry Clin Pract [Internet]. 2006 Jan 12;10(sup1):3-9. Available from: http://www.tandfonline.com/doi/full/10.1080/13651500600552297

70. Ohannessian $\mathrm{CM}$. The interactive effect of paternal problem drinking and maternal problem drinking on adolescent internalizing problems. Addict Behav. 2015 Nov;50:70-3.

71. Gagnier JJ, Moher D, Boon H, Beyene J, Bombardier C. Investigating clinical heterogeneity in systematic reviews: a methodologic review of guidance in the literature. BMC Med Res Methodol [Internet]. 2012 Dec 30;12(1):111. Available from: http://bmcmedresmethodol.biomedcentral.com/articles/10.1186/1471-2288-12-111

72. Mahesh PKB, Gunathunga MW, Arnold SM, Jayasinghe C, Pathirana S, Makarim MF, et al. Effectiveness of targeting fathers for breastfeeding promotion: Systematic review and metaanalysis. BMC Public Health. 2018.

\section{Tables}


Table 1: Characteristics of the studies selected for Meta-analysis 


\begin{tabular}{|c|c|c|c|c|c|}
\hline Study & Setting & Population/s & Exposure measurements & $\begin{array}{l}\text { Selected } \\
\text { outcomes } \\
\text { measurements }\end{array}$ & $\begin{array}{l}\text { Effect } \\
\text { measure }\end{array}$ \\
\hline $\begin{array}{l}\text { 1.Choi, } \\
\text { 2013(29) }\end{array}$ & $\begin{array}{l}\text { Chungam } \\
\text { province, Korea }\end{array}$ & $\begin{array}{l}950 \text { students in } \\
\text { an academic } \\
\text { high school }\end{array}$ & $\begin{array}{l}\text { By Father-Short Michigan } \\
\text { Alcoholism Screening Test. Filled } \\
\text { by children. }\end{array}$ & $\begin{array}{l}\text {-Depression } \\
\text { with Beck's } \\
\text { Depression } \\
\text { Inventory } \\
\text {-Anxiety with } \\
\text { Beck's Anxiety } \\
\text { Inventory } \\
\text {-Measurements } \\
\text { were taken at a } \\
\text { mean gae of } \\
16.5 \text { years } \\
\end{array}$ & $\mathrm{MD}$ \\
\hline $\begin{array}{l}2 . \\
\text { Edwards, } \\
2001(27)\end{array}$ & $\begin{array}{l}\text { New York, } \\
\text { United states }\end{array}$ & $\begin{array}{l}\text { A cohort of } \\
213 \text { families in a } \\
\text { longitudinal } \\
\text { study }\end{array}$ & $\begin{array}{l}\text { Family History Research } \\
\text { Diagnostic Criteria (RDC) for } \\
\text { alcoholism by the partner as well } \\
\text { as by the responses of the father } \\
\text { for University of Michigan } \\
\text { Composite Diagnostic Index (UM- } \\
\text { CIDI) and with DSM-IV criteria }\end{array}$ & $\begin{array}{l}\text {-2-3 year } \\
\text { version of the } \\
\text { Child Behavior } \\
\text { Checklist } \\
\text { (CBCL) } \\
\text {-Selected } \\
\text { measurements } \\
\text { were when the } \\
\text { child was } 18 \\
\text { months }\end{array}$ & $\mathrm{MD}$ \\
\hline $\begin{array}{l}3 . \\
\text { Edwards, } \\
2006(28)\end{array}$ & $\begin{array}{l}\text { New York, } \\
\text { United states }\end{array}$ & $\begin{array}{l}\text { A cohort of } \\
191 \text { families in a } \\
\text { longitudinal } \\
\text { study. Analysis } \\
\text { was done for } \\
176 \text { families }\end{array}$ & $\begin{array}{l}\text { RDC, UM-CIDI and DSM IV } \\
\text { criteria }\end{array}$ & $\begin{array}{l}\text {-CBCL } \\
\text {-Selected } \\
\text { measurements } \\
\text { were when the } \\
\text { child was three } \\
\text { years }\end{array}$ & $\mathrm{MD}$ \\
\hline $\begin{array}{l}\text { 4. Eiden, } \\
\text { 2009(30) }\end{array}$ & $\begin{array}{l}\text { New York, } \\
\text { United States }\end{array}$ & $\begin{array}{l}112 \text { children } \\
\text { with parent } \\
\text { alcoholic group } \\
\text { and } 101 \text { without } \\
\text { alcoholic group. }\end{array}$ & $\begin{array}{l}\text { RDC, UM-CIDI and DSM IV } \\
\text { criteria }\end{array}$ & $\begin{array}{l}\text {-Relevant } \\
\text { subscales of } \\
\text { CBCL } \\
\text {-Revised Child } \\
\text { Manifest } \\
\text { Anxiety Scale } \\
\text {-Child } \\
\text { Depression } \\
\text { Inventory } \\
\text { - } \\
\text { Measurements } \\
\text { were done at } \\
\text { Grade } 4\end{array}$ & $\mathrm{MD}$ \\
\hline $\begin{array}{l}5 . \\
\text { Haugland } \\
2003(31)\end{array}$ & Norway & $\begin{array}{l}37 \text { families with } \\
\text { paternal } \\
\text { alcohol } \\
\text { problems and } \\
1170 \text { general }\end{array}$ & Cahalan's questionnaire & $\begin{array}{l}\text {-Child Behavior } \\
\text { Checklist } \\
\text {-Measurements } \\
\text { were done } \\
\text { between 7-11 } \\
\text { years }\end{array}$ & $\mathrm{MD}$ \\
\hline
\end{tabular}




\begin{tabular}{|c|c|c|c|c|c|}
\hline & & $\begin{array}{l}\text { population } \\
\text { sample }\end{array}$ & & & \\
\hline $\begin{array}{l}\text { 6. Jacob, } \\
\text { 1999(32) }\end{array}$ & $\begin{array}{l}\text { California, } \\
\text { United States }\end{array}$ & $\begin{array}{l}297 \text { offspring of } \\
\text { families those } \\
\text { had } \\
\text { participated in } \\
\text { an assessment } \\
5 \text { years back }\end{array}$ & SADS-L questionnaire & $\begin{array}{l}\text {-RDC diagnosis } \\
\text {-Mean age at } \\
\text { outcome } \\
\text { assessment } \\
\text { was } 23.8 \text { years }\end{array}$ & OR \\
\hline $\begin{array}{l}\text { 7. Jacob, } \\
\text { 2000(33) }\end{array}$ & $\begin{array}{l}\text { California, } \\
\text { United States }\end{array}$ & $\begin{array}{l}\text {-393 adult } \\
\text { offspring of } \\
\text { families having } \\
\text { participated in } \\
\text { an assessment } \\
10 \text { years back }\end{array}$ & RDC, DSM IV & $\begin{array}{l}\text {-NEO- } \\
\text { Personality } \\
\text { Inventory } \\
\text {-RDC for } \\
\text { depressive } \\
\text { disorder and } \\
\text { anxiety } \\
\text { disorder } \\
\text {-Social } \\
\text { Adjustment } \\
\text { Scale-Self } \\
\text { Report } \\
\text {-Mean age at } \\
\text { outcome } \\
\text { measurement } \\
\text { was 27.1 years } \\
\end{array}$ & OR \\
\hline $\begin{array}{l}8 . \\
\text { Loukas, } \\
2001(34)\end{array}$ & United States & $\begin{array}{l}\text { Male children } \\
\text { from } 125 \\
\text { families with ad } \\
83 \text { families } \\
\text { without an } \\
\text { alcoholic father }\end{array}$ & -Lifetime Alcohol Problems Score & $\begin{array}{l}\text {-Child Behavior } \\
\text { Checklist } \\
\text {-Measurements } \\
\text { were done at 6- } \\
8 \text { years }\end{array}$ & $\mathrm{MD}$ \\
\hline $\begin{array}{l}9 . \\
\text { Morgan, } \\
2010(35)\end{array}$ & $\begin{array}{l}\text { Data from } \\
\text { National } \\
\text { Epidemiological } \\
\text { data from } \\
\text { United States }\end{array}$ & $\begin{array}{l}43093 \text { non- } \\
\text { institutionalized } \\
\text { residents. } \\
\text { Sample used } \\
\text { for analysis } \\
\text { consisted of } \\
40374\end{array}$ & $\begin{array}{l}\text {-DSM IV version of Alcohol Use } \\
\text { Disorder and Associated } \\
\text { Disabilities Interview Schedule }\end{array}$ & $\begin{array}{l}\text {-DSM IV } \\
\text { version of } \\
\text { Alcohol Use } \\
\text { Disorder and } \\
\text { Associated } \\
\text { Disabilities } \\
\text { Interview } \\
\text { Schedule } \\
\text {-Respondents } \\
\text { were } 18 \text { years } \\
\text { or over }\end{array}$ & OR \\
\hline $\begin{array}{l}10 . \\
\text { Puttler, } \\
1998(36)\end{array}$ & $\begin{array}{l}\text { Michigan, } \\
\text { United States }\end{array}$ & $\begin{array}{l}212 \text { families of } \\
\text { the MSU-UM } \\
\text { Longitudinal } \\
\text { study }\end{array}$ & $\begin{array}{l}\text {-Diagnosis made by trained } \\
\text { clinicians using DSM-IV criteria }\end{array}$ & $\begin{array}{l}\text {-Child Behavior } \\
\text { Checklist- } \\
\text { Parent Version } \\
\text { (CBCL) } \\
\text {-Mean age of } \\
\text { respondents } \\
\text { was } 5.63 \text { years }\end{array}$ & $\mathrm{MD}$ \\
\hline $\begin{array}{l}\text { 11. Singh } \\
2017(37)\end{array}$ & $\begin{array}{l}542 \text { Schools in } \\
\text { Chandigarh, }\end{array}$ & $\begin{array}{l}\text { School going } \\
\text { adolescents }\end{array}$ & $\begin{array}{l}\text {-Using a structured questionnaire } \\
\text { based on literature review }\end{array}$ & $\begin{array}{l}\text {-Patient Health } \\
\text { Questionnaire- }\end{array}$ & OR \\
\hline
\end{tabular}


Table 2: Characteristics of the studies selected for narrative review 


\begin{tabular}{|c|c|c|c|c|}
\hline Study & Setting & Population & $\begin{array}{l}\text { Exposure } \\
\text { measurements }\end{array}$ & Outcome measurements \\
\hline $\begin{array}{l}1 . \\
\text { Adkison, } \\
2013(38)\end{array}$ & $\begin{array}{l}\text { United } \\
\text { States }\end{array}$ & $\begin{array}{l}197 \text { families with } 12 \text { month-old } \\
\text { infants at recruitment }\end{array}$ & $\begin{array}{l}\text { RDC, UM-CIDI and } \\
\text { DSM IV criteria }\end{array}$ & $\begin{array}{l}\text {-Stroop Color and Word } \\
\text { Test } \\
\text { - Tower of London task } \\
\text {-Stop-Signal Reaction Time } \\
\text {-Measurements were done } \\
\text { in grades } 4 \text { and } 6\end{array}$ \\
\hline $\begin{array}{l}\text { 2. Balsa, } \\
\text { 2009(39) }\end{array}$ & $\begin{array}{l}\text { United } \\
\text { States }\end{array}$ & $\begin{array}{l}12686 \text { youths between years } \\
14 \text { and } 22 \text { in } 1979, \text { Re- } \\
\text { assessments were done until } \\
1994\end{array}$ & $\begin{array}{l}\text { Questionnaire of } \\
\text { National } \\
\text { Longitudinal } \\
\text { Survey of Youth, } \\
1979\end{array}$ & $\begin{array}{l}\text {-SF-12 Mental Health } \\
\text { Index } \\
\text { - Diagnosis of a mental } \\
\text { health condition in last } 12 \\
\text { months(39)- Diagnosis of } \\
\text { a mental health condition } \\
\text { ever } \\
\text {-Measurements were done } \\
\text { at } 40 \text { years }\end{array}$ \\
\hline
\end{tabular}

\begin{tabular}{|c|c|c|c|c|}
\hline $\begin{array}{l}\text { 3. Chen, } \\
\text { 2005(47) }\end{array}$ & $\begin{array}{l}\text { United } \\
\text { States }\end{array}$ & $\begin{array}{l}\text { A nationally representative } \\
\text { sample of college students of } \\
27430\end{array}$ & $\begin{array}{l}\text {-DSM-IV } \\
\text { approximate } \\
\text { criteria }\end{array}$ & $\begin{array}{l}\text {-Mental Health subscale of } \\
\text { SF-36 }\end{array}$ \\
\hline $\begin{array}{l}4 . \\
\text { Cuijpers, } \\
1999(48)\end{array}$ & Netherlands & $\begin{array}{l}\text { A random sample of Dutch } \\
\text { population (N=7147) with } \\
\text { data from "Netherlands } \\
\text { Mental Health Survey and } \\
\text { Incidence Study" }\end{array}$ & $\begin{array}{l}\text {-Respondents' self- } \\
\text { reports }\end{array}$ & -Respondents' self-reports \\
\hline $\begin{array}{l}5 . \\
\text { Edwards, } \\
2006 b(49)\end{array}$ & $\begin{array}{l}\text { United } \\
\text { States }\end{array}$ & $\begin{array}{l}\text { A sample of } 226 \text { families } \\
\text { selected from birth records for } \\
\text { Erie County }\end{array}$ & $\begin{array}{l}\text { RDC, UM-CIDI and } \\
\text { DSM IV criteria }\end{array}$ & $\begin{array}{l}\text {-Aggression subscale of } \\
\text { the CBCL } \\
\text {-Measurements were done } \\
\text { at child age of } 18,24,36 \\
\text { and } 48 \text { months }\end{array}$ \\
\hline $\begin{array}{l}\text { 6. Eiden, } \\
\text { 2001(50) }\end{array}$ & $\begin{array}{l}\text { United } \\
\text { States }\end{array}$ & $\begin{array}{l}215 \text { families with 12-month old } \\
\text { children }\end{array}$ & $\begin{array}{l}\text { RDC, UM-CIDI and } \\
\text { DSM IV criteria }\end{array}$ & $\begin{array}{l}\text {-According to guidelines of } \\
\text { Kochanska and Akshan } \\
\text { (1995) } \\
\text {-Measurements were done } \\
\text { at } 18 \text { and } 24 \text { months }\end{array}$ \\
\hline $\begin{array}{l}\text { 7. Finan, } \\
\text { 2015(51) }\end{array}$ & $\begin{array}{l}\text { United } \\
\text { States }\end{array}$ & $\begin{array}{l}\text { Adolescents from 14-19 years } \\
\text { and their parents }\end{array}$ & $\begin{array}{l}\text { Short Michigan } \\
\text { Alcoholism } \\
\text { Screening Test }\end{array}$ & $\begin{array}{l}\text {-Child Behavior Checklist } \\
\text {-Mean age of the } \\
\text { participants was } 16.15 \\
\text { years }\end{array}$ \\
\hline $\begin{array}{l}\text { 8. Foley } \\
2001(67)\end{array}$ & $\begin{array}{l}\text { United } \\
\text { States }\end{array}$ & 850 twin families & DSM-III-R criteria & $\begin{array}{l}\text {-Child and Adolescent } \\
\text { Psychiatric Assessment- } \\
\text { Children's Version (CAPA- } \\
\text { C) } \\
\text {-Ages of twins was } \\
\text { between of 8-17 years }\end{array}$ \\
\hline $\begin{array}{l}\text { 9. Grekin, } \\
\text { 2005(52) }\end{array}$ & $\begin{array}{l}\text { Brisbane, } \\
\text { Australia }\end{array}$ & $\begin{array}{l}816 \text { families with children } \\
\text { born between 1981-1984 in a } \\
\text { Mother's Hospital }\end{array}$ & $\begin{array}{l}\text { Using structured } \\
\text { Clinical Interview } \\
\text { for the DSM-IV }\end{array}$ & $\begin{array}{l}\text {-Self-report items from } \\
\text { National Youth Survey }\end{array}$ \\
\hline
\end{tabular}


-The mean age of the sample was 15 years and two months

\begin{tabular}{|c|c|c|c|c|}
\hline $\begin{array}{l}\text { 10. Keller, } \\
\text { 2008(53) }\end{array}$ & $\begin{array}{l}\text { United } \\
\text { States }\end{array}$ & $\begin{array}{l}235 \text { families from a midsize } \\
\text { and large city }\end{array}$ & $\begin{array}{l}\text { Parental Alcohol } \\
\text { Experiences Scale }\end{array}$ & $\begin{array}{l}\text {-Internalizing and } \\
\text { externalizing subscales of } \\
\text { CBSL } \\
\text {-Data collection was done } \\
\text { at baseline, } 1 \text { year later } \\
\text { and } 2 \text { years later }\end{array}$ \\
\hline $\begin{array}{l}\text { 11. Kelley } \\
\text { 2010(46) }\end{array}$ & $\begin{array}{l}\text { Southeastern } \\
\text { United } \\
\text { States } \\
\end{array}$ & $\begin{array}{l}627 \text { students attending a } \\
\text { university }\end{array}$ & $\begin{array}{l}\text { Children of } \\
\text { Alcoholics } \\
\text { Screening test } \\
\end{array}$ & $\begin{array}{l}\text { Depression-Dejection } \\
\text { subscale of the Profile of } \\
\text { Mood States questionnaire }\end{array}$ \\
\hline $\begin{array}{l}12 . \\
\text { Kelley, } \\
2011(54)\end{array}$ & $\begin{array}{l}\text { United } \\
\text { States }\end{array}$ & $\begin{array}{l}436 \text { undergraduate university } \\
\text { students in southeastern } \\
\text { Virginia }\end{array}$ & $\begin{array}{l}\text { Children of } \\
\text { Alcoholics } \\
\text { Screening Test }\end{array}$ & $\begin{array}{l}\text {-Profile of Mood States } \\
\text { questionnaire } \\
\text {-The average age was } \\
21.93 \text { years }\end{array}$ \\
\hline $\begin{array}{l}13 . \\
\text { Knopik, } \\
2005(40)\end{array}$ & $\begin{array}{l}\text { United } \\
\text { States }\end{array}$ & $\begin{array}{l}1936 \text { adolescent female twin } \\
\text { pairs born during 1975-1985 }\end{array}$ & $\begin{array}{l}\text { DSM-IV } \\
\text { incorporated Semi- } \\
\text { Structured } \\
\text { Assessment of the } \\
\text { Genetics of } \\
\text { Alcoholism }\end{array}$ & $\begin{array}{l}\text {-Items derived from the } \\
\text { Diagnostic Interview for } \\
\text { Children and Adolescents } \\
\text {-Average age was } 14.4 \\
\text { years }\end{array}$ \\
\hline $\begin{array}{l}14 . \\
\text { Knopik } \\
2009(45)\end{array}$ & Vietnam & $\begin{array}{l}727 \text { twin fathers, and } 1116 \\
\text { children }\end{array}$ & $\begin{array}{l}\text { DSM-IV } \\
\text { incorporated Semi- } \\
\text { Structured } \\
\text { Assessment of the } \\
\text { Genetics of } \\
\text { Alcoholism }\end{array}$ & $\begin{array}{l}\text {-Items derived from the } \\
\text { Diagnostic Interview for } \\
\text { Children and Adolescents } \\
\text {-Average child age was } \\
\text { 19.1 years }\end{array}$ \\
\hline $\begin{array}{l}15 . \\
\text { Malone } \\
2002(41)\end{array}$ & $\begin{array}{l}\text { Minnesota, } \\
\text { United } \\
\text { States }\end{array}$ & 2426 twin subjects & $\begin{array}{l}\text { Using substance } \\
\text { abuse module }\end{array}$ & $\begin{array}{l}\text {-Revised Diagnostic } \\
\text { Interview for Children and } \\
\text { Adolescents } \\
\text {-Twins were } 11 \text { or } 17 \text { years } \\
\text { of age }\end{array}$ \\
\hline $\begin{array}{l}16 . \\
\text { Raitasala } \\
2018(42) \\
\end{array}$ & Finland & $\begin{array}{l}57377 \text { children born in1997 } \\
\text { and their parents }\end{array}$ & $\begin{array}{l}\text { Using ICD-10 } \\
\text { criteria }\end{array}$ & $\begin{array}{l}\text {-Using ICD-10 criteria } \\
\text {-Children were followed up } \\
\text { until the end of } 2012 \\
\end{array}$ \\
\hline $\begin{array}{l}17 . \\
\text { Tripkovic } \\
2013(44) \\
\end{array}$ & Croatia & $\begin{array}{l}\text { Sample of } 701 \text { school students } \\
\text { from } 14-19 \text { years }\end{array}$ & $\begin{array}{l}\text { Using a specially } \\
\text { designed } \\
\text { questionnaire } \\
\end{array}$ & $\begin{array}{l}\text { Using the Report on Youth } \\
\text { Aged 11-18 and the Scale } \\
\text { of Auto-destructiveness }\end{array}$ \\
\hline $\begin{array}{l}18 . \\
\text { Sundquist } \\
2014(43)\end{array}$ & Sweden & 49348 individuals with ADHD & $\begin{array}{l}\text { ICD-9 and ICD-10 } \\
\text { guidelines }\end{array}$ & $\begin{array}{l}\text {-ICD-9 and ICD-10 codes } \\
-46.3 \% \text { were between 10- } \\
19 \text { years }\end{array}$ \\
\hline
\end{tabular}

Due to technical limitations, Table 3 has been placed in the supplementary files section. 


\begin{tabular}{|c|c|c|c|c|c|}
\hline & fect of $p$ & al alcohol & on the psyc & social well-being of children & \\
\hline \multirow[t]{2}{*}{ Outcome } & \multicolumn{2}{|c|}{$\begin{array}{c}\text { Anticipated absolute } \\
\text { effect } \\
\end{array}$} & \multirow{2}{*}{$\begin{array}{c}\text { No of } \\
\text { participants } \\
\text { (studies) }\end{array}$} & \multirow[t]{2}{*}{ Comments } & \multirow{2}{*}{$\begin{array}{l}\text { Quality of } \\
\text { evidence/ } \\
\text { GRADE }\end{array}$} \\
\hline & $\begin{array}{l}\text { Risk of } \\
\text { comparison } \\
\text { group }\end{array}$ & $\begin{array}{l}\text { Risk of the } \\
\text { children } \\
\text { with } \\
\text { alcoholic } \\
\text { fathers }\end{array}$ & & & \\
\hline $\begin{array}{l}\text { Internalizing } \\
\text { behavior }\end{array}$ & $\mathrm{N} / \mathrm{A}$ & $\begin{array}{l}\text { MD } 2.02 \\
\text { higher } \\
(1.16 \\
\text { higher to } \\
2.88 \\
\text { higher) }\end{array}$ & $\begin{array}{l}1742(4 \\
\text { studies / } \\
6 \\
\text { comparisons })\end{array}$ & $\begin{array}{l}\text { Exposed group had significantly higher } \\
\text { means in three sub-groups }(28,31) \text { and } \\
\text { higher non-significant means in three } \\
\text { sub-groups }(27,36)\end{array}$ & Low $^{\mathrm{C}}$ \\
\hline $\begin{array}{l}\text { Externalizing } \\
\text { behavior }\end{array}$ & $\mathrm{N} / \mathrm{A}$ & $\begin{array}{l}\text { MD } 2.13 \\
\text { higher } \\
(1.11 \\
\text { higher to } \\
3.16 \\
\text { higher) }\end{array}$ & $\begin{array}{l}1614 \text { (5 } \\
\text { studies / } \\
7 \text { sub-group) }\end{array}$ & $\begin{array}{l}\text { Exposed group had statistically } \\
\text { significant higher means in three sub- } \\
\text { groups }(28,31,34) \text { and higher non- } \\
\text { significant means in two sub- } \\
\text { groups }(27,31) \\
\text { One study was excluded from meta- } \\
\text { analysis considering statistical } \\
\text { heterogeneity(36) }\end{array}$ & Low $^{\mathrm{d}}$ \\
\hline Anxiety & $\mathrm{N} / \mathrm{A}$ & $\begin{array}{l}\text { MD } 0.72 \\
\text { higher } \\
(0.2 \text { higher } \\
\text { to } 1.23 \\
\text { higher }) \\
\end{array}$ & $\begin{array}{l}1316(2 \\
\text { studies/ } \\
4 \\
\text { comparisons })\end{array}$ & $\begin{array}{l}\text { Exposed group had significantly higher } \\
\text { means in one sub-group(29) and } \\
\text { statistically non-significant higher } \\
\text { values in three sub-groups }(29,30)\end{array}$ & Low $^{b}$ \\
\hline Depression & $\mathrm{N} / \mathrm{A}$ & $\begin{array}{ll}\text { MD } & 3.20 \\
\text { higher } & \\
(1.72 & \\
\text { higher } & \text { to } \\
4.69 & \\
\text { higher) } & \end{array}$ & $\begin{array}{l}960 \text { (1 study/ } \\
2 \text { sub- } \\
\text { groups) }\end{array}$ & $\begin{array}{l}\text { Exposed group had significantly higher } \\
\text { means in both sub-groups (29) }\end{array}$ & Low $^{b}$ \\
\hline
\end{tabular}

MD- mean difference, N/A- not applicable,

a,b,c,d started with a low baseline rating as these were non-RCT studies and were not up-graded

Table 5: Summary of Finding Table for the meta-analyses of categorical outcomes

\begin{tabular}{llllll}
\hline Outcomes & Assumed risk $^{\mathrm{a}}$ & Corresponding risk & Relative effect & $\begin{array}{l}\text { No. of participants } \\
\text { (studies })\end{array}$ & $\begin{array}{l}\text { Quality of evidence } \\
\text { GRADE }\end{array}$ \\
\hline Anxiety & 95 per 1000 & $\begin{array}{l}\text { 186 per 1000 } \\
(176 \text { to } 197)\end{array}$ & OR=2.18 & $\begin{array}{l}40640 \\
(2.03-2.33)\end{array}$ & Moderate $^{\mathrm{C}}$ \\
& & & & \\
\hline
\end{tabular}

aTotal events divided by the total participants in the control group

bFunction of "assumed risk" and the "relative effect"

c started with a low baseline rating as non-RCT studies and up-graded for "large magnitude effect" (1 point) 
Table 6: Sensitivity analysis with random and fixed model assumptions

\begin{tabular}{|c|c|c|c|c|}
\hline & Heterogeneity & $\begin{array}{c}\text { Effect } \\
\text { measure } \\
(\mathrm{CI})\end{array}$ & $\begin{array}{l}\text { Heterogeneity } \\
\text { For SMD }\end{array}$ & $\begin{array}{l}\text { SMD } \\
(\mathrm{CI})\end{array}$ \\
\hline $\begin{array}{l}\text { Internalizing behavior with fixed-model } \\
\text { assumption }\end{array}$ & $\begin{array}{l}\mathrm{I}^{2} \text { value- } 0 \% \\
\mathrm{P}=0.58\end{array}$ & $\begin{array}{c}\mathrm{MD}=2.02 \\
(1.16 \text { to } \\
2.88)\end{array}$ & $\begin{array}{c}\mathrm{I}^{2} \text { value- } 42 \% \\
\mathrm{P}=0.13\end{array}$ & $\begin{array}{c}\mathrm{SMD}= \\
0.34 \\
(0.21 \text { to } \\
0.47)\end{array}$ \\
\hline $\begin{array}{l}\text { Internalizing behavior with random-model } \\
\text { assumption }\end{array}$ & $\begin{array}{l}\mathrm{I}^{2} \text { value- } 0 \% \\
\mathrm{P}=0.58\end{array}$ & $\begin{array}{c}\mathrm{MD}=2.02 \\
(1.16 \text { to } \\
2.88)\end{array}$ & $\begin{array}{c}\mathrm{I}^{2} \text { value- } 42 \% \\
\mathrm{P}=0.13\end{array}$ & $\begin{array}{c}\mathrm{SMD}= \\
0.36 \\
(0.18 \text { to } \\
0.53)\end{array}$ \\
\hline $\begin{array}{l}\text { Externalizing behavior with fixed-model } \\
\text { assumption }\end{array}$ & $\begin{array}{l}\mathrm{I}^{2} \text { value- } 0 \% \\
\mathrm{P}=0.44\end{array}$ & $\begin{array}{c}\mathrm{MD}=2.13 \\
(1.11 \text { to } \\
3.16)\end{array}$ & $\begin{array}{c}\mathrm{I}^{2} \text { value }-46 \% \\
\mathrm{P}=0.12\end{array}$ & $\begin{array}{c}\mathrm{SMD}= \\
0.34 \\
(0.20 \text { to } \\
0.48)\end{array}$ \\
\hline $\begin{array}{l}\text { Externalizing behavior with random-model } \\
\text { assumption }\end{array}$ & $\begin{array}{l}\mathrm{I}^{2} \text { value- } 0 \% \\
\mathrm{P}=0.44\end{array}$ & $\begin{array}{c}\mathrm{MD}=2.17 \\
(1.02 \text { to } \\
3.32)\end{array}$ & $\begin{array}{c}\mathrm{I}^{2} \text { value }-46 \% \\
\mathrm{P}=0.12\end{array}$ & $\begin{array}{c}\mathrm{SMD}=0.35 \\
(0.16 \text { to } \\
0.55)\end{array}$ \\
\hline Anxiety (numerical) with fixed-model assumption & $\begin{array}{l}\mathrm{I}^{2} \text { value- } 31 \% \\
\mathrm{P}=0.23\end{array}$ & $\begin{array}{c}\mathrm{MD}=0.72 \\
(0.20 \text { to } \\
1.23)\end{array}$ & $\begin{array}{l}\mathrm{I}^{2} \text { value- } 0 \% \\
\mathrm{P}=0.58\end{array}$ & $\begin{array}{c}\mathrm{SMD}= \\
0.21 \\
(0.09 \text { to } \\
0.33)\end{array}$ \\
\hline $\begin{array}{l}\text { Anxiety (numerical) with random-model } \\
\text { assumption }\end{array}$ & $\begin{array}{c}\mathrm{I}^{2} \text { value- } 31 \% \\
\mathrm{P}=0.23\end{array}$ & $\begin{array}{c}\mathrm{MD}=0.95 \\
(0.06 \text { to } \\
1.85)\end{array}$ & $\begin{array}{l}\mathrm{I}^{2} \text { value- } 0 \% \\
\mathrm{P}=0.58\end{array}$ & $\begin{array}{c}\mathrm{SMD}= \\
0.21 \\
(0.09 \text { to } \\
0.33)\end{array}$ \\
\hline $\begin{array}{l}\text { Depression (numerical) with fixed-model } \\
\text { assumption }\end{array}$ & $\begin{array}{l}\mathrm{I}^{2} \text { value- } 0 \% \\
\mathrm{P}=0.72\end{array}$ & $\begin{array}{c}\mathrm{MD}=3.20 \\
(1.72 \text { to } \\
4.69)\end{array}$ & $\begin{array}{l}\mathrm{I}^{2} \text { value- } 0 \% \\
\mathrm{P}=0.84\end{array}$ & $\begin{array}{c}\mathrm{SMD}= \\
0.36 \\
(0.22 \text { to } \\
0.51)\end{array}$ \\
\hline $\begin{array}{l}\text { Depression (numerical) with random-model } \\
\text { assumption }\end{array}$ & $\begin{array}{l}\mathrm{I}^{2} \text { value- } 0 \% \\
\mathrm{P}=0.72\end{array}$ & $\begin{array}{c}\mathrm{MD}=3.20 \\
(1.72 \text { to } \\
4.69)\end{array}$ & $\begin{array}{l}\mathrm{I}^{2} \text { value- } 0 \% \\
\mathrm{P}=0.84\end{array}$ & $\begin{array}{c}\mathrm{SMD}= \\
0.36 \\
(0.22 \text { to } \\
0.51)\end{array}$ \\
\hline $\begin{array}{l}\text { Anxiety (categorical) with fixed-model } \\
\text { assumption }\end{array}$ & $\begin{array}{l}\mathrm{I}^{2} \text { value- } 0 \% \\
\mathrm{P}=0.78\end{array}$ & $\begin{array}{c}\mathrm{OR}=2.18 \\
(2.03 \text { to } \\
2.33)\end{array}$ & Not relevant & $\begin{array}{l}\text { Not } \\
\text { relevant }\end{array}$ \\
\hline $\begin{array}{l}\text { Anxiety (categorical) with random-model } \\
\text { assumption }\end{array}$ & $\begin{array}{l}\mathrm{I}^{2} \text { value- } 0 \% \\
\mathrm{P}=0.78\end{array}$ & $\begin{array}{c}\mathrm{OR}=2.18 \\
(2.03 \text { to } \\
2.33)\end{array}$ & Not relevant & $\begin{array}{l}\text { Not } \\
\text { relevant }\end{array}$ \\
\hline
\end{tabular}

\section{Figures}


Search strategy implemented

\section{$\downarrow$}

Number of journal articles identified with the title $=16398$

With de-duplication and title/abstract review

16157 articles were excluded in the first round.
Number of articles selected for the second review $=241$

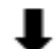

Number of articles selected for the third review $=113$

Number of articles selected for the data

extraction $=29$

-11 were included in meta-analysis(27-

37)

-18 were include only in narrative

review(38-54)
128 articles were excluded in the second round.

- Different outcome=111

- Qualitative review only $=17$
84 articles were excluded in the third round

- Unclear exposed/control group= 44

- Analysis only include both parents= 40

\section{Figure 1}

Flow of the selection process of articles

\begin{tabular}{lllll}
\hline Population & Exposure & Comparison & Outcome & Study design \\
\hline -Eligibility & -How was the & -Number of & -Primary and & -Type of design \\
criteria & exposure defined & comparison & secondary & -Year of conduct \\
-Characteristics & & groups & outcomes & -Study setting \\
of the & -Number & -How the & \\
participants & participated in & outcomes were \\
& the paternal non- & measured \\
& alcoholic arm & -Number of & \\
& & exposure & participants with \\
& & each outcome & \\
& & &
\end{tabular}

\section{Figure 2}


Extracted variables

Internalizing behavior

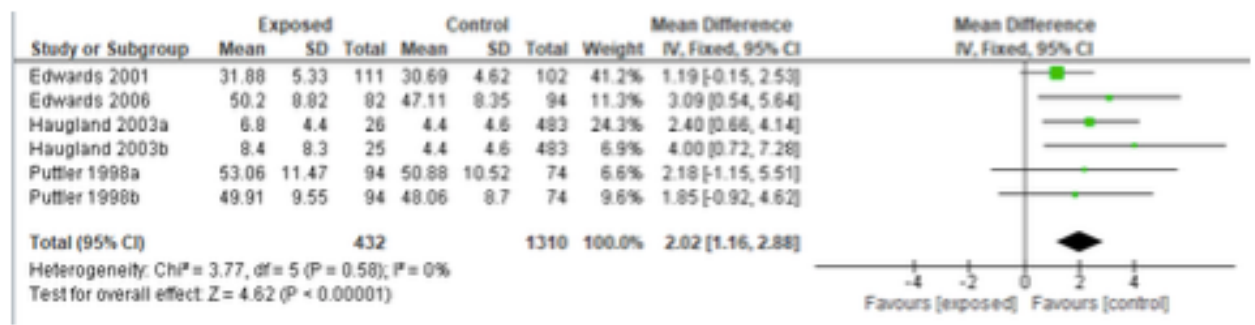

Figure 3A: Forrest plot for the outcome of "internalizing behavior"

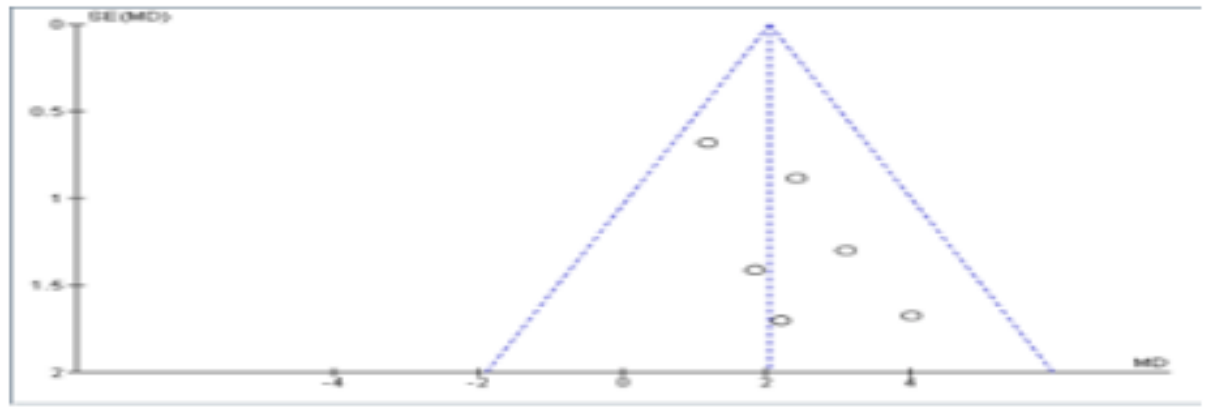

Figure 3B: Funnel plot for the outcome of "internalizing behavior"

\section{Figure 3}

3A: Forrest plot for the outcome of "internalizing behavior". 3B: Funnel plot for the outcome of "internalizing behavior" 


\section{Externalizing behavior}

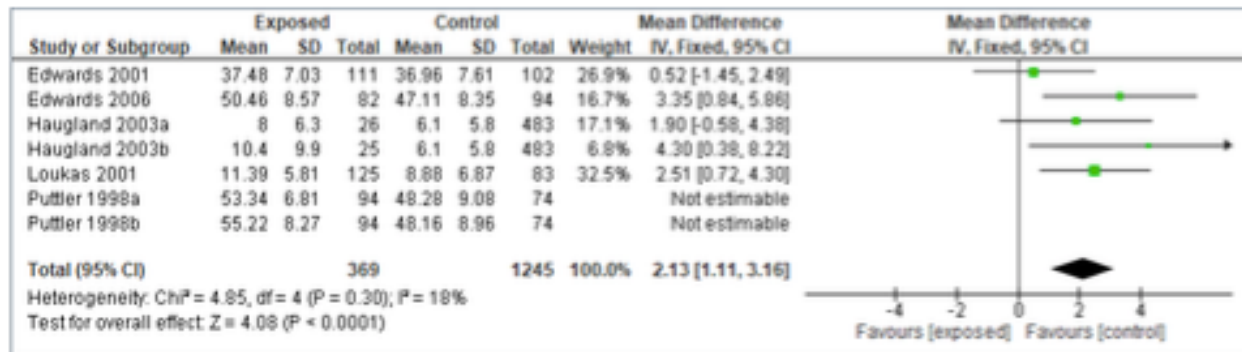

Figure 4A: Forrest plot for the outcome of "externalizing behavior"

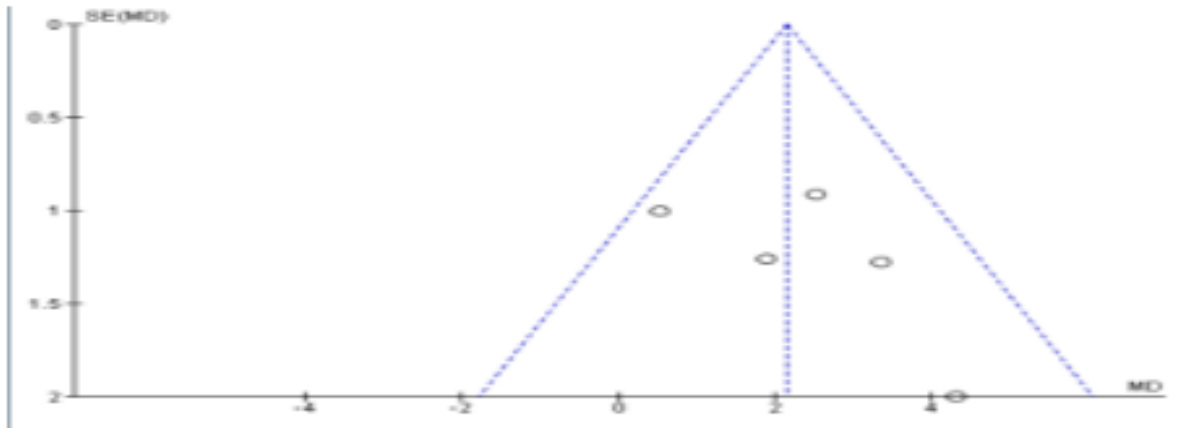

Figure 4B: Funnel plot for the outcome of "externalizing behavior"

\section{Figure 4}

4A; Forrest plot for the outcome of "externalizing behavior". 4B: Funnel plot for the outcome of "externalizing behavior" 
Anxiety as a numerical variable

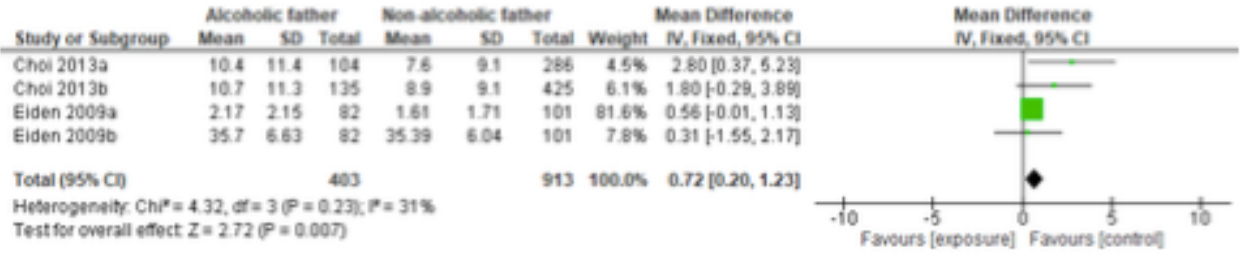

Figure 5A: Forrest plot for the outcome of "anxiety as a numerical variable"

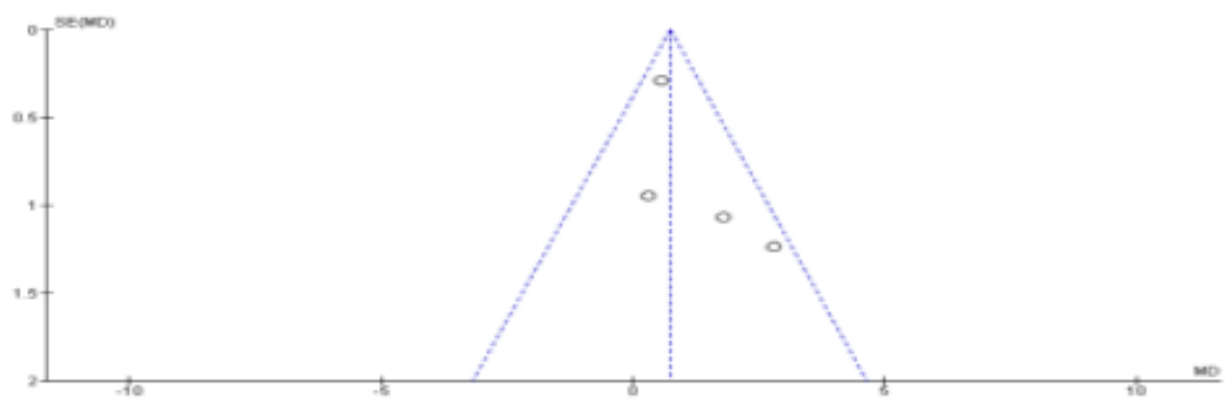

Figure 5B: Funnel plot for the outcome of "anxiety as a numerical variable"

\section{Figure 5}

5A: Forrest plot for the outcome of "anxiety as a numerical variable". 5B: Funnel plot for the outcome of "anxiety as a numerical variable"

\section{Depression as a numerical variable}

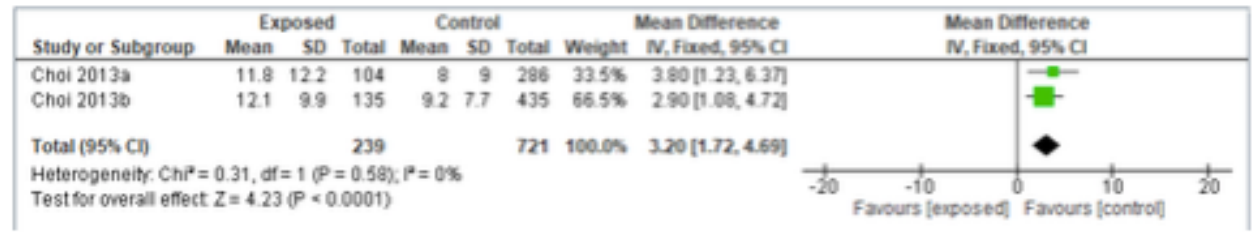

Figure 6A: Forrest plot for the outcome of "depression"

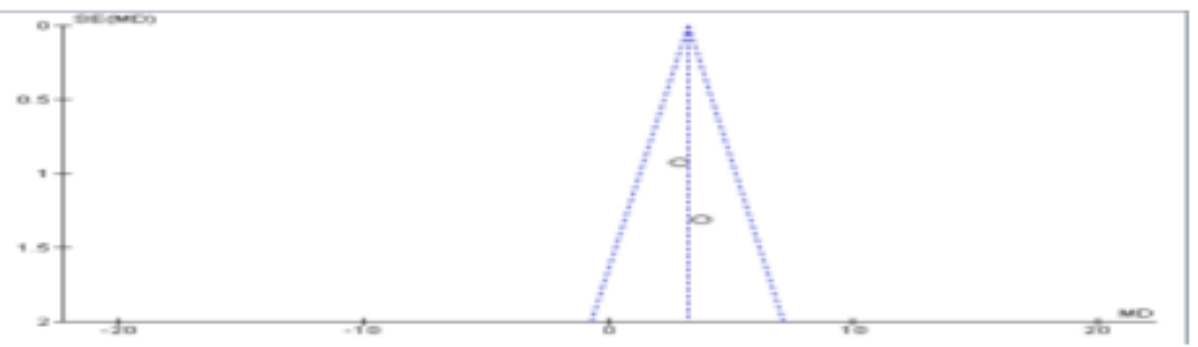

Figure 6B: Funnel plot for the outcome of "depression" 
Figure 6

6A: Forrest plot for the outcome of "depression". 6B: Funnel plot for the outcome of "depression" Anxiety as a categorical variable

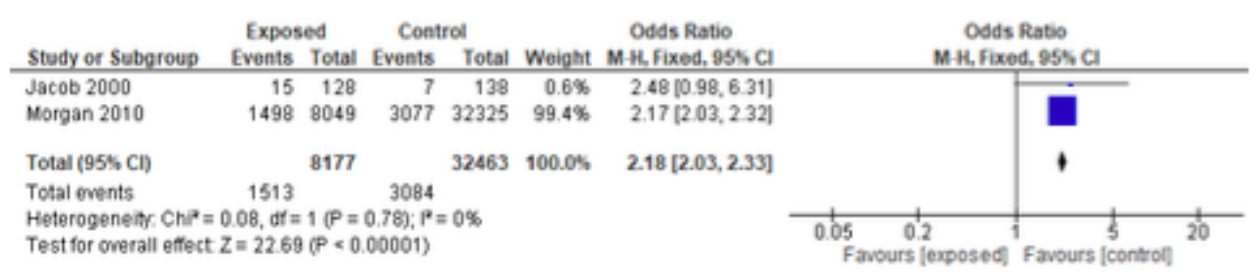

Figure 7A: Forrest plot for the outcome of "anxiety as a categorical variable"

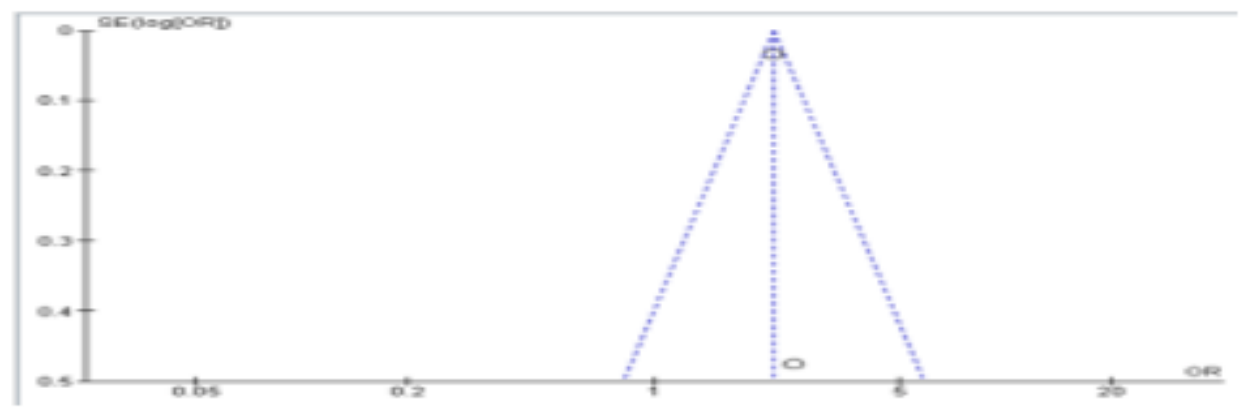

Figure 7B: Funnel plot for the outcome of "anxiety as a categorical variable"

Figure 7

7A: Forrest plot for the outcome of "anxiety as a categorical variable". 7B: Funnel plot for the outcome of "anxiety as a categorical variable"

\section{Supplementary Files}

This is a list of supplementary files associated with this preprint. Click to download.

- Table3.png

- Supplementarymaterials.docx

- FilledPRISMA2009checklistforBMCPediatricts.docx 